\author{
ACTA MYCOLOGICA \\ Vol. 43 (2): 121-132 \\ 2008
}

\title{
Glomus intraradices and Pacispora robiginia, species of arbuscular mycorrhizal fungi (Glomeromycota) new for Poland
}

\author{
JANUSZ BŁASZKOWSKI ${ }^{1}$, BEATA CZERNIAWSKA ${ }^{1}$, SZYMON ZUBEK $^{2}$ \\ and KATARZYNA TURNAU ${ }^{3}$
}

\author{
${ }^{1}$ Department of Plant Pathology, University of Agriculture \\ Słowackiego 17, PL-71-434 Szczecin, jblaszkowski@agro.ar.szczecin.pl \\ ${ }^{2}$ Department of Pharmaceutical Botany, Faculty of Pharmacy, Jagiellonian University Collegium \\ Medicum Medyczna 9, PL-30-688 Kraków, zubek@cm-uj.krakow.pl \\ ${ }^{3}$ Institute of Environmental Sciences, Jagiellonian University \\ Gronostajowa 7, PL-30-387 Kraków, katarzyna.turnau@uj.edu.pl
}

Błaszkowski J., Czerniawska B., Zubek Sz., Turnau K.: Glomus intraradices and Pacispora robiginia, species of arbuscular mycorrhizal fungi (Glomeromycota) new for Poland. Acta Mycol. 43 (2): 121-132, 2008.

Morphological characters of spores and mycorrhizae of Glomus intraradices, as well as spores of Pacispora robiginia, arbuscular mycorrhizal fungi of the phylum Glomeromycota, were described and illustrated. Additionally, the known distribution of these species in both Poland and other regions of the world was presented. Both the species were not so far recorded in Poland and this paper is the second report of the finding of P. robiginia in the world.

Key words: Glomus intraradices, Glomeromycota, Pacispora robiginia, distribution

\section{INTRODUCTION}

Investigations of the occurrence of arbuscular mycorrhizal fungi of the phylum Glomeromycota in Poland revealed Glomus intraradices N.C. Schenck et G.S. Sm. and Pacispora robiginia Sieverd. et Oehl. Both fungi were not so far recorded in Poland and this paper is the second report of the finding of $P$. robiginia in the world.

The aim of this paper is to present morphological characters of the G. intraradices and $P$. robiginia specimens found, as well as the known distribution of these fungi in the world.

\section{MATERIALS AND METHODS}

Establishment and growth of trap and one-species cultures, extraction of spores, and staining of mycorrhizae. Spores examined in this study came from both pot trap and one-species cultures. Trap cultures were established to obtain a great number 
of living spores of different developmental stages and to initiate sporulation of species that were present but not sporulating in the field collections (Stutz, Morton 1996). The method used to establish trap cultures, their growing conditions, and the method of spore extraction were previously described (Błaszkowski et al. 2004).

One-species cultures were also generally established and grown as given in Błaszkowski et al. (2004), with two exceptions. First, instead of marine sand, their growing medium was an autoclaved commercially available coarse-grained sand (grains 1.0-10.0 mm diam. - 80.50\%; grains 0.1-1.0 mm diam. - 17.28\%; grains < $0.1 \mathrm{~mm}$ diam. - $2.22 \%$ ) mixed $(5: 1, \mathrm{v} / \mathrm{v})$ with clinopthilolite (Zeocem, Bystré, Slovakia) of grains 2.5-5 mm. Clinopthilolite is a crystaline hydrated alumosilicate of alkali metals and alkaline earth metals having, e.g., a high ion exchange capability and selectivity, as well as a reversible hydration and dehydration. $\mathrm{pH}$ of the sand-clinopthilolite mixture was 7.3. Second, the cultures were kept in transparent plastic bags, $15 \mathrm{~cm}$ wide and $22 \mathrm{~cm}$ high as suggested by Walker and Vestberg (1994), rather than open pot cultures (Gilmore 1968). To prevent contamination of the cultures with other AMF but still to allow exchange of gases, we left an opening, $c a .1 \mathrm{~cm}$ wide, in the centre of the upper part of each bag, while the edges on both sides were closed with small plastic clips. The cultures were watered with tap water once a weak, harvested after five months when spores were extracted for study. To reveal mycorrhizae, root fragments located $c a$. $1-5 \mathrm{~cm}$ below the upper level of the growing medium were cut off with a scalpel. The host plant used in both trap and one-species cultures was Plantago lanceolata L.

Microscopy survey. Morphological properties of spores and their wall structure were determined based on examinations of at least 100 spores mounted in polyvinyl alcohol/lactic acid/glycerol (PVLG; Omar, Bollan, Heather 1979) and a mixture of PVLG and Melzer's reagent $(1: 1, \mathrm{v} / \mathrm{v})$. Spores at all developmental stages were crushed to varying degrees by applying pressure to the cover slip and then stored at $65^{\circ} \mathrm{C}$ for $24 \mathrm{~h}$ to clear their contents from oil droplets. These were then examined under an Olympus BX 50 compound microscope equipped with Nomarski differential interference contrast optics. Microphotographs were recorded on a Sony 3CDD color video camera coupled to the microscope.

Terminology of spore structure is that suggested by Stürmer and Morton (1997) and Walker $(1983,1986)$. Spore colour was examined under a dissecting microscope on fresh specimens immersed in water. Colour names are from Kornerup and Wanscher (1983). Nomenclature of fungi and plants is that of Walker and Trappe (1993) and Mirek et al. (1995), respectively. The authors of the fungal names are those presented at the Index Fungorum website http://www.indexfungorum.org/AuthorsOfFungalNames.htm. Specimens were mounted in PVLG on slides and deposited in the Department of Plant Pathology, University of Agriculture, Szczecin, Poland.

Colour microphotographs of spores and mycorrhizae of the fungi presented here can be viewed at the URL http://www.agro.ar.szczecin.pl/ jblaszkowski/.

\section{DESCRIPTIONS OF THE SPECIES}

Glomus intraradices N.C. Schenck et G.S. Sm.

Spores occur in aggregates or singly in the soil, and frequently are formed inside of roots (Figs 1 and 2). Aggregates pale yellow (3A3) to greyish yellow (2B5); of a different shape, usually ovoid 0.3-1.8 x 1.0-3.0 mm; containing from 2 to more than 100 
spores (Fig. 1). Spores origin blastically at the tip of either branched hyphae (when in aggregates) or non-branched hyphae (when single) continuous with mycorrhizal extraradical hyphae. Spores hyaline, when juvenile, pale yellow (3A3) to greyish yellow (2B5), frequently with a greenish tint, when mature; globose to subglobose; (30-)92(-120) $\mu \mathrm{m}$ diam; occasionally ovoid to irregular; 46-90 x 62-120 $\mu \mathrm{m}$ (Figs 1 and 2). Subcellular structure of spores consists of a spore wall comprising three layers (layers 1-3; Figs 3-6). Layer 1, forming the spore surface, mucilaginous, (0.7-)1.4 $(-2.5) \mu \mathrm{m}$ thick, always highly deteriorated or completely sloughed in mature spores. Layer 2 semipermanent, semiflexible, hyaline, (2.2-)3.0(-3.9) $\mu \mathrm{m}$ thick, more or less deteriorating with age and either retaining as a granular structure or completely sloughed at maturity. Layer 3 laminate, pale yellow (3A3) to greyish yellow (2B5), (2.0-)6.7(-11.0) $\mu \mathrm{m}$ thick, consisting of one (in juvenile spores) to more than $20 \mathrm{sub}$ layers (laminae), each ca. 0.5-1.0 $\mu \mathrm{m}$ thick, usually easily separating from each other in crushed spores. The spore colour darkens with the increasing number and thickness of the laminae during differentiation of the spore wall. In Melzer's reagent, only layer 1 stains bluish red (12A8) to cerise (12C8; Figs 3-6). Subtending hypha pale yellow (3A3) to greyish yellow (2B5); straight or curved; cylindrical or slightly flared, occasionally slightly constricted at the spore base; (13.7-)15.5(-18.4) $\mu \mathrm{m}$ wide at the spore base (Fig. 6). Wall of subtending hypha pale yellow (3A3) to greyish yellow (2B5); (2.7-)5.1(-6.6) $\mu \mathrm{m}$ thick at the spore base; composed of three layers continuous with spore wall layers 1-3 (Fig. 6); layer 1 extends up to $25 \mu \mathrm{m}$ below the spore base, and layer 2 , when young, develops along the whole subtending hypha and also is a component of the wall of both the branched hyphae of aggregates and the non-branched hyphae continuous with mycorrhizal extraradical hyphae. Pore 3.4-8.1 $\mu \mathrm{m}$ wide, open (Fig. 6). Germination. Not observed by the authors of this paper. According to Morton (2002) and Stürmer and Morton (1997), spores of G. intraradices appear to germinate by a germ tube arising from the innermost sublayer (lamina) of the spore wall layer 3. Then, the germ tube emerges from the lumen of the subtending hypha. Additionally, in some specimens, a germ tube arises from broken ends of hyphal fragments some distance from the spore base. This behaviour probably accounts for the high infectivity of hyphal fragments of this species.

MyCORRHIZAE. In one-species pot cultures with P. lanceolata as the host plant, mycorrhizae of $G$. intraradices consisted of arbuscules, vesicles, as well as intra- and extraradical hyphae (Figs 7 and 8). Arbuscules were very numerous and evenly distributed along the root fragments examined. They consisted of a trunk grew from a parent hypha and many branches with very fine tips (Fig. 7). Vesicles occurred sporadically and were widely dispersed along the axis of the root fragments (Fig. 8). They were ellipsoid; 20.0-32.0 x 27.5-60.0 $\mu \mathrm{m}$. The intraradical hyphae usually extended parallel to the root axis and were (2.0-)4.0(-5.6) $\mu \mathrm{m}$ wide. They sometimes formed Y-or H-shaped branches and frequently coils (Fig. 8). The coils were ellipsoid; 15.0-20.0 x 40.0-97.5 $\mu \mathrm{m}$; rarely circular; 35.0-45.0 $\mu \mathrm{m}$ diam; when observed in a plane view. The extraradical hyphae were (1.7-)2.5(-4.4) $\mu \mathrm{m}$ wide and occurred abundantly. In $0.1 \%$ trypan blue, arbuscules stained pale violet (16A3) to royal purple (16D8), vesicles light lilac (16A5) to royal purple (16D8), intraradical hyphae violet white (16A2) to reddish violet (16A8), coils violet white (16A2) to reddish violet (16C8), and extraradical hyphae violet white (15A2) to reddish violet (16A8; Figs 7 and 8). 
Phylogenetic position. Results of molecular analyses have accommodated G. intraradices in subclade b of Glomus group A in the family Glomeraceae Piroz. et Dalpé of the order Glomerales J.B. Morton et Benny, also comprising G. clarum Nicol. et N.C. Schenck, G. coremioides (Berk. et Broome) D. Redecker et J.B. Morton, G. fasciculatum (Thaxt.) Gerd. et Trappe emend. C. Walker et Koske, G. manihotis R.H. Howeler, Sieverd. et N.C. Schenck, G. proliferum Dalpe et Declerck, G. sinuosum (Gerd. et B.K. Bakshi) R.T. Almeida et N.C. Schenck, and G. vesiculiferum (Thaxt.) Gerd. et Trappe (Schwarzott, Walker, Schüßler 2001). Unfortunately, the phylogenetic distance between G. intraradices and G. aggregatum N.C. Schenck et G.S. Sm. emend. Koske, G. antarcticum M. Cabello, G. aureum Oehl et Sieverd., G. cerebriforme McGee, G. glomerulatum Sieverd., G. invermaium I.R. Hall, and G. pallidum I.R. Hall, species compared below as well, remains unknown to date.

Distribution AND HABITAT. In Poland, the authors of this paper found spores of G. intraradices in 25 samples of rhizosphere soils and roots. Of them, five came from under Ammophila arenaria (L.) Link, Artemisia campestris L. and Petasites spurius (Retz.) Rchb. colonizing maritime sand dunes adjacent to Świnoujście $\left(53^{\circ} 55^{\prime} \mathrm{N}\right.$, $1^{\circ} 14^{\prime} \mathrm{E}$ ) in October 1993 and June 1997, three from under P. lanceolata growing in

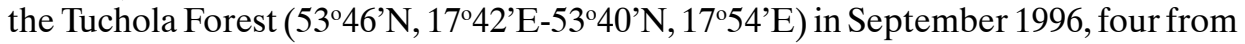
under Festuca rubra L. s. s. and Holcus mollis L. colonizing the inland sand dunes of the Błędowska Desert (50²2'N, 19³4'E) in June 1997, five from under A. arenaria and Agrostis stolonifera L. growing in maritime sand dunes of the Słowiński National Park $\left(54^{\circ} 45^{\prime} \mathrm{N}, 17^{\circ} 26^{\prime} \mathrm{E}\right)$ in August 1996, one from under Hieracium sp. growing in an arsenic heap near Złoty Stok $\left(50^{\circ} 26^{\prime} \mathrm{N}, 16^{\circ} 52^{\prime} \mathrm{E}\right)$ and sampled in July 2002, four from under Taxus baccata L. growing in the Central Cemetery in Szczecin $\left(53^{\circ} 26^{\prime} \mathrm{N}\right.$, $14{ }^{\circ} 35^{\prime} \mathrm{E}$ ) in May 2001, and four from under Juncus conglomeratus L. em. Leers colonizing the bank of the Puck Bay (54\%42'N, 1828'E) in August 2001.

Additionally, Turnau et al. (2001) detected G. intraradices in roots of Fragaria vesca L. colonizing a 20-year-old Zn waste located in Chrzanów $\left(50^{\circ} 08^{\prime} \mathrm{N}, 19^{\circ} 24^{\prime} \mathrm{E}\right)$ in southern Poland using a nested polymerase chain reaction with taxon-specific primers, although no spores of this fungus were found.

The holotype of $G$. intraradices has been selected from spores extracted from pot-cultured Paspalum notatum Flugge initiated from a sample originally isolated from among roots of Citrus sp. cultivated in Orlando, Florida, U.S.A. (Schenck, Smith 1982). Schenck and Smith $(1981,1982)$ found this species to be one of the most common Glomus species occurring in Florida, where it was associated with roots of many plant species.

Literature data and investigations of the authors of this paper indicate G. intraradices to have a worldwide distribution. Apart from Poland and Florida, this fungus has also been encountered in many other regions of the U.S.A., e. g., in California (Bethlenfalvay, Dakessian, Pacovscky 1984; Koske, Halvorson 1989), Kentucky (An et al. 1993), Massachusetts (Błaszkowski, unpubl. data), Texas (Stutz, Morton 1996) and Hawaii (Koske, Gemma 1996), as well as in Canada (Dalpé 1989; Klironomos et al. 2001), Portugal (Błaszkowski, unpubl. data), Bornholm (Denmark; Błaszkowski, unpubl. data), Switzerland (Jansa et al. 2002; Oehl et al. 2005), Africa (Błaszkowski, unpubl. data; Stutz et al. 2000), Israel (Błaszkowski, Czerniawska 2006), Turkey and Cyprus (Błaszkowski, unpubl. data), China (Gai et al. 2006; Zhang, Wang 1992), and India (Mohankumar et al. 1988). 
Our investigations of field-collected mixtures of rhizosphere soils and roots and those sampled from trap cultures established from a part of the field mixtures revealed that the arbuscular fungi co-occurring with $G$. intraradices were Acaulospora lacunosa J.B. Morton, A. mellea Spain et N.C. Schenck, A. morrowiae Spain et N.C. Schenck, Archaeospora trappei (R.N. Ames et Linderman) J.B. Morton et D. Redecker emend. Spain, Entrophospora baltica Błaszk., Madej et Tadych, G. aggregatum, G. arenarium Błaszk., Tadych et Madej, G. clarum, G. constrictum Trappe, G. corymbiforme Błaszk., G. deserticola Trappe, Bloss et J.A. Menge, G. etunicatum W.N. Becker et Gerd., G. fasciculatum, G. gibbosum Błaszk., G. insculptum Błaszk., G. macrocarpum Tul. et C. Tul., G. microcarpum Tul. et C. Tul., G. lamellosum Dalpé, Koske et Tews, G. pustulatum Koske, Friese, C. Walker et Dalpé, an undescribed Glomus sp., Paraglomus laccatum (Błaszk.) C. Renker, Błaszk. et F. Buscot, Scutellospora armeniaca Koske et Halvorson, and S. dipurpurescens J.B. Morton et Koske.

The spore abundance of $G$. intraradices in the field samples ranged from 1 to 30 in $100 \mathrm{~g}$ dry soil, and the proportion of spores of this fungus in spore populations of all the arbuscular fungi isolated ranged from 0.7 to $33.3 \%$.

Collections examined. Africa: Tunisia, Sousse (35ํ5'스, 10³8'E), under Ammophila arenaria (L.) Link, 20 Sept. 2006, J. Błaszkowski, 2733 (DPP); Cyprus: near Larnaca $\left(34^{\circ} 55^{\prime} \mathrm{N}, 33^{\circ} 38^{\prime} \mathrm{E}\right)$, among roots of Oenothera drummondii Hook., 23 Oct. 2003, J. Błaszkowski, unnumbered collection (DPP); Denmark: Bornholm, near

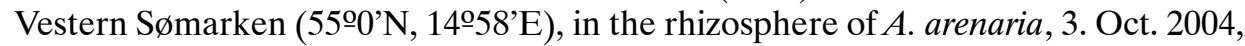
J. Błaszkowski, 2730 (DPP); Israel: near Tel-Aviv (32²'N, 3446'E), around roots of $O$. drummondii, 15 June 2000, J. Błaszkowski, unnumbered collection (DPP); Poland: Świnoujście, under $A$. arenaria and Petasites spurius (Retz.) Rchb., 6 Oct. 1993, under Artemisia campestris L., 13 June 1997, J. Błaszkowski, 2717-2729 and 2731-2732 (DPP); Tuchola Forest, among roots of P. lanceolata, 21 Sept. 1996, J. Błaszkowski, unnumbered collection (DPP); the Błędowska Desert, in the rhizosphere of Festuca rubra L. s. s. and Holcus mollis L., 26 June 1997, J. Błaszkowski, unnumbered collection (DPP); Słowiński National Park, associated with roots of Agrostis stolonifera L. and A. arenaria, 2 and 3 Aug. 1996, J. Błaszkowski, unnumbered collection (DPP); Złoty Stok, under Hieracium sp., at the end of June 2002, unnumbered collection (DPP); Szczecin, among roots of Taxus baccata L., 2 May 2001, J. Błaszkowski, unnumbered collection (DPP); Osłonino, in the rhizosphere of Juncus conglomeratus L. em. Leers, 1 Sept. 2000, J. Błaszkowski, unnumbered collection (DPP); Portugal: Faro ( $\left.37^{\circ} 1^{\circ} \mathrm{N}, 7^{\circ} 36^{\prime} \mathrm{W}\right)$, among roots of $A$. arearia, 10 June 2001, J. Błaszkowski, unnumbered collection (DPP); Turkey: near Karabucak-Tuzla (36 $\left.43^{\circ} \mathrm{N}, 34^{\circ} 59^{\prime} \mathrm{E}\right)$, in the rhizosphere of $A$. arenaria, 10 June 2001, J. Błaszkowski, unnumbered collection (DPP); U.S.A.: Massachusetts, under A. breviligulata Fern., 15 Oct. 2002, J. Błaszkowski, unnumbered collection (DPP).

Notes. When observed under a dissecting microscope, three groups of species of the genus Glomus known to form spores both singly and in aggregates more or less resemble $G$. intraradices. The group of species most similar in colour and size of spores to those of $G$. intraradices is represented by $G$. aggregatum, $G$. antarcticum, $G$. fasciculatum, G. pallidum, G. proliferum, and G. vesiculiferum.

Considering the phenotypic and biochemical properties of the components of the spore wall of these species observed under a light microscope, $G$. intraradices is 
most closely related to G. aggregatum. The number and the types of layers forming the spore wall of these species and their reactivity in Melzer's reagent are identical (Błaszkowski 2003; pers. observ.). The only character distinguishing these fungi is the formation of spores inside of their parent spores by internal proliferation in G. aggregatum (Koske 1985), a phenomenon not found in G. intraradices (Błaszkowski, pers.observ.; Stürmer, Morton 1997). Morton (2002) hypothesized these species to be synonymous. Thus, results of molecular analyses of both fungi are urgently needed to explain this supposition.

Similarly as in G. intraradices, the spore wall of G. antarcticum and G. fasciculatum is 3-layered (Błaszkowski 2003; Cabello, Gaspar, Pollero 1994; Walker, Koske 1987). However, of these layers of G. antarcticum, only the outermost one, forming the spore surface, sloughs with age. In contrast, in G. intraradices, two outer spore wall layers are of the type of sloughing layers (Figs 3-6). Moreover, the spore wall of G. intraradices lacks the innermost, flexible layer of the G. antarcticum spore wall. Finally, while the outermost spore wall layer of $G$. intraradices stains intensively in Melzer's reagent (Figs 3-6), none of the wall layers of G. antarcticum spores reacts in this reagent.

As mentioned above, G. fasciculatum also produces spores of a 3-layered wall, of which all are permanent, however (Błaszkowski 2003; Walker, Koske 1987; vs. two outer layers slough with age in G. intraradices; Figs 3-6). Similarly as in G. antarcticum, the distinctive component of the spore wall of $G$. fasciculatum is an innermost flexible, colourless layer, which is lacking in the wall of spores of $G$. intraradices. Still other important difference between these fungi regards the reactivity of their spores in Melzer's reagent. While the structure of spores of $G$. intraradices staining in this reagent is only their outermost spore wall layer (Figs 3-6), two outer wall layers of spores of $G$. fasciculatum are reactive in Melzer's reagent, including its laminate layer, not staining in any other known species of the genus Glomus (Błaszkowski, pers. observ.). Additionally, G. intraradices probably is much more plastic ecologically than G. fasciculatum. The former fungus has successfully been used in many experiments (Gopi, Douds, Douds 2000). Although G. fasciculatum has been one of the most frequently cited species of arbuscular fungi in papers describing the influence of arbuscular fungi on plants, Walker and Koske (1987) concluded this fungus to had certainly been confused with other species of the Glomeromycota. Many attempts to grow G. fasciculatum in one-species cultures made by one of the authors of this paper (J. Błaszkowski) failed. In the literature, there is no convincing evidence of the properties of mycorrhizae of $G$. fasciculatum from a one-species culture.

Although G. proliferum has originally been described to form hyaline spores (Declerck et al. 2000), pictures obtained from Dr. C. Walker, U. K., also show yellowcoloured spores of this fungus, deceptively similar to those of $G$. intraradices. However, in respect of size, only the largest spores of the former species attain the lower size range of spores of the latter fungus (Błaszkowski, pers. observ.; Declerck et al. 2000). The spore wall of $G$. proliferum has originally been characterized to consist of four permanent layers, but examination of this fungus (culture: MVCL 41827) obtained from Prof. S. Declerck, Université catholique de Louvain, Mycothèque de l'Université catholique de Louvain, Unite de microbiologie, Belgium, revealed only three layers of phenotypic and biochemical properties identical to those of G. intraradices. 
At least three morphological characters separate G. intraradices and G. pallidum. First, Hall (1977) characterized spores of the latter species to be whitish, and not yellow-coloured as most mature spores of the former fungus (Fig. 1). Second, spores of $G$. pallidum generally are smaller than those of $G$. intraradices [32-78 x 28-68 $\mu \mathrm{m}$ diam according to Hall 1977; vs. (30-)92(-120) $\mu \mathrm{m}$ diam or (60-)80-120(-160) $\mu \mathrm{m}$ diam as the authors of this paper and Stürmer and Morton (1997) determined, respectively]. Third, in contrast to the 3-layered spore wall of $G$. intraradices (Figs 3-6), only two layers build the spore wall of G. pallidum. Among them, the middle, semi-flexible wall layer of $G$. intraradices spores is lacking.

The unique structures of $G$. vesiculiferum are its thin-walled vesicles associated with a peridium-like layer covering sporocarps of this fungus (Gerdemann, Trappe 1974). Additionally, spores of $G$. vesiculiferum generally are smaller (49-85 $\mu \mathrm{m}$ diam when globose or up to $100 \times 70 \mu \mathrm{m}$ when ovoid to irregular; Gerdemann and Trappe 1974 ) than those of $G$. intraradices (see above) and have only a 2-layered wall (Gerdemann, Trappe 1974 vs. 3-layered in G. intraradices; Figs 3-6).

The second group of species compared here represents only G. cerebriforme, whose spores partly overlap in size with those of $G$. intraradices [25 x 25-65 x $80 \mu \mathrm{m}$ diam after McGee (1986) vs. (30-)92(-120) $\mu \mathrm{m}$ diam or (60-)80-120(-160) $\mu \mathrm{m}$ diam according to Błaszkowski et al. (pers. observ.) and Stürmer and Morton (1997), respectively], but remain hyaline throughout their entire life cycle, and, thereby, are similar only to the juvenile spores (Błaszkowski et al., pers. observ.) of the species discussed here. Moreover, the distinctive character of the former species is the formation of its spores on racemose hyphae, and not on hyphae irregularly branched as in the latter fungus.

The next diametrical differences between these species occur in the number, the phenotypic characters, and the spatial distribution of layers of their spore wall. The spore wall of $G$. cerebriforme consists of a thick, laminate outer layer and a thin, flexible inner one (McGee 1986). Thus, the structural layer of this wall is an outermost layer, forming the spore surface, and not an innermost one as in the spore wall of G. intraradices, which is covered with two impermanent layers (Figs 3-6), but does not overly a flexible layer as in $G$. cerebriforme. Additionally, compared with $G$. intraradices, the subtending hypha of $G$. cerebriforme spores is much narrower [3-7 $\mu \mathrm{m}$ wide after McGee (1986) vs. (13.7-)15.5(-18.4) $\mu \mathrm{m}$ wide as presented here].

The third group of species superficially resembling $G$. intraradices comprises G. aureum, G. glomerulatum, and G. invermaium. Compared with the relatively large (92-120 $\mu \mathrm{m}$ diam when globose) and pale yellow (3A3) to greyish yellow (2B5) mature spores of $G$. intraradices (Błaszkowski et al., pers. observ.; Fig. 1), globose spores of all the other species are smaller and darker-coloured [(27-)40-60 $\mu \mathrm{m}$ diam, light orange $(5 \mathrm{~A} 4)$ to orange $(5 \mathrm{~A} 7)$ in $G$. aureum; Błaszkowski et al., pers. observ.; Oehl et al. 2003; 40-70 $\mu \mathrm{m}$ diam, light orange (5A5) to golden yellow (5B8) in G. glomerulatum; Błaszkowski et al., pers. observ.; Sieverding 1987; 50-75 $\mu \mathrm{m}$ diam, light brown to brown in $G$. invermaium; Hall 1977]. Except for G. intraradices having a 3-layered spore wall (Figs 3-6), that of all these species is 2-layered. Moreover, the layers forming the spore surface of $G$. glomerulatum and $G$. invermaium are laminate and unit sensu Walker (1983), respectively, thus, they are permanent, whereas the outermost spore wall layer of $G$. intraradices lives shortly and usually is completely sloughed or at most occurs patchily as a highly decomposed structure at maturity (Fig. 4). 
The distinctive character of spores of $G$. glomerulatum also is that the innermost layer of their wall is a thin, flexible, membranous, uniform structure, and not a rigid layer composed of many sublayers (laminae) as in the other three species and that G. glomerulatum produces only intercalary spores, which, thereby, always have two subtending hyphae (Błaszkowski et al., pers. observ.; Sieverding 1987). An intercalary mode of spore origination has also been observed in $G$. intraradices and many other species of the Glomeromycota (Błaszkowski et al., pers. observ.), but such spores usually constituted a small part of all the spores produced.

The last morphological character distinguishing species of this group is the width of the subtending hyphae of their spores. It is widest in G. intraradices [(13-7)15.5 (-18.4) $\mu \mathrm{m}$ wide; Błaszkowski et al., pers. observ.], intermediate in G. invermaium (6-13 $\mu \mathrm{m}$ wide; Hall 1977), and narrowest in G. glomerulatum (6-10 $\mu \mathrm{m}$ wide; Błaszkowski et al., pers. observ.; Sieverding 1987).

As presented in the section "Phylogenetic position", apart from species compared above, $G$. intraradices is molecularly also related to G. clarum, G. coremioides, G. manihotis, and G. sinuosum (Schwarzott et al. 2001).

Although there is no formal decision, morphological characters and results of molecular analyses of spores of G. clarum and G. manihotis have suggested these fungi to be synonymous (Morton 2002; Schwarzott et al. 2001). Morphologically, $G$. clarum differs markedly from $G$. intraradices in colour and size of spores, as well as in phenotypic properties of the components of their wall. Spores of the former fungus may be darker [to yellow-brown; Morton 2002; vs. pale yellow (3A3) to greyish yellow (2B5) or hyaline to greenish yellow after Błaszkowski et al., pers. observ. and Stürmer and Morton 1997, respectively], much larger when globose [(120-)180200(-280) $\mu \mathrm{m}$ diam; Stürmer and Morton 1997; vs. (30-)92(-120) $\mu \mathrm{m}$ diam or (60)80-120(-160) $\mu \mathrm{m}$ diam after Błaszkowski et al., pers. observ. and Stürmer, Morton 1997, respectively], and have two laminate layers in their 3-layered wall (vs. only one such layer in G. intraradices; Figs 3-6).

Glomus coremioides and G. sinuosum are morphologically completely unlike $G$. intraradices. The former two fungi produce compact sporocarps with a peridium (Błaszkowski et al., pers. observ.; Gerdemann, Trappe 1974; Morton 2002; vs. single spores or in loose aggregates without a peridium in $G$. intraradices), in which spores are organized in a single layer and develop from a central plexus of hyphae (vs. randomly distributed spores when in aggregates and develop terminally from branched hyphae; Fig. 1). Moreover, spores of the former two species are (1) ovoid to clavate (vs. usually globose to subglobose in $G$. intraradices), (2) darker-coloured [brown and orange-brown, respectively, after Gerdemann, Trappe 1974 and Morton 2002, respectively; vs. pale yellow (3A3) to greyish yellow (2B5) in G. intraradices; Błaszkowski et al., pers. observ.], and (3) their wall consists of only one layer (Błaszkowski et al., pers. observ.; Gerdemann, Trappe 1974; Morton 2002; vs. 3-layered in G. intraradices; Figs 3-6).

Pacispora robiginia Sieverd. et Oehl

Spores produced singly in the soil, blastically at the tip of mycorrhizal extraradical hyphae. Spores pale orange (5A3) to golden yellow (5B7); globose to subglobose; (100-)125-155(-161) $\mu \mathrm{m}$ diam; rarely ellipsoidal; 95-135 x 135-165 $\mu \mathrm{m}$; with a single subtending hypha (Figs 9-14). Subcellular structure of spores consists of a spore wall 
and an inner germination wall (Figs 9-14). Spore wall consists of three layers (layers 1-3; Figs 9-14). Layer 1, forming the spore surface, permanent, of a smooth upper surface, unit, pale orange (5A3) to golden yellow (5B7), 2.5-3.5(-5.0) $\mu$ m thick, tightly adherent to layer 2. Layer 2 laminate, light orange (5A4-5), 4.0-6.5 $\mu \mathrm{m}$ thick. Layer 3 permanent, concolorous with layer $2,<0.5 \mu \mathrm{m}$ thick, usually tightly adherent to the lower surface of layer 2 in even vigorously crushed spores and, hence, very difficult to observe. Germination wall includes three hyaline layers (layers 1-3; Figs 9-14). Layer 1 flexible, 0.4-0.8 $\mu \mathrm{m}$ thick, usually separates from layer 2 in crushed spores. Layer 2 coriaceous, 2.2-3.0 $\mu \mathrm{m}$ thick. Layer 3 flexible, $<1.0 \mu \mathrm{m}$ thick, usually tightly adherent to the lower surface of layer 2, sometimes wrinkles in spores vigorously crushed in PVLG. In Melzer's reagent, only layer 2 of the germination wall stains pare red (9A3; Fig. 13). Subtending hypha light orange (5A4-5) at the spore base and for some distance from the spore base; usually straight, sometimes slightly curved; cylindrical; 8-15 $\mu \mathrm{m}$ wide at the spore base, 12-25 $\mu \mathrm{m}$ at a some distance from the spore base (Fig. 14). Wall of subtending hypha light orange (5A4-5) for some distance from the spore base, then gradually lightens up to hyaline; 2.6-3.8 $\mu \mathrm{m}$ thick at the spore base, $<1 \mu \mathrm{m}$ thick 30-80(-100) $\mu \mathrm{m}$ below the spore base, composed of two layers continuous with spore wall layers 1 and 2 (Fig. 14). Pore closed at the spore base by a transverse septum formed by spore wall layer 2 and by adherent spore wall layer 3. Germination shield. Not found. Germination. Unknown.

MyCORRHIZAE. Pacispora robiginia has been associated with mycorrhizal roots of plants of grasslands (Oehl, Sieverding 2004). However, attempts to grow this fungus in one-species cultures failed and, hence, the properties of mycorrhizae of $P$. robiginia remain unknown.

Distribution. The type of $P$. robiginia has been selected from spores isolated from a calcareous Lithic Leptosol in the High Alpines at the Haldensteiner Calanda ( $\left.9^{\circ} 27^{\prime} \mathrm{E}, 46^{\circ} 53^{\prime} \mathrm{N}\right)$ at $2800 \mathrm{~m}$ above the see level, near Chur (Kanton Graubünden), Switzerland (Oehl, Sieverding 2004). The same scientists have also found this fungus among roots of plants of High Alpine grasslands located in the Gotthard region (Kanton Wallis), Central Switzerland.

In Poland, one of the authors of this paper (Sz. Zubek) isolated spores of P. robiginia from under Soldanella carpatica Viehr. growing in Tatra Mountains.

Collections eXAmined. Poland: Tatra Mountains, Kozi Grzbiet (49¹4’N, 1953'), under S. carpatica, 5 Sept. 2004, J. Błaszkowski, 2734 and 2735 (DPP); Switzerland: Dr. F. Oehl's specimens: T12701, 33211005; MZ2690, 11031004; DS2483, 15280904; Ax2701, 26220704; AX2700, 21220704; DS2537, 05280904; TI2704, Aloenis14071004; TI2701, 07071004; MJ2690, 14031004; MJ2690, 12031004; DS52537, 06280904; TI2701, 32211005; MJ2690, 20041004; Ax2665, 35071004; IC2888, 03240504; IC2890, 01240504; IC2800，13240504; MJ2690， 13031004; Ax2675，36071004; IC2800, 17240504; HC2600, 26130704; GR2600, 20220304 ; GR2600, 09220304.

Notes. Under a dissecting microscope, spores of $P$. robiginia resemble yellowcoloured spores of many species of the genus Glomus. Examination of the subcellular structure of spores of the former fungus under a compound microscope readily reveals its main generic character, i. e., the inner complex and relatively thick germination wall (Figs 9-14) resembling a germination wall of spores of fungi of the genus Scutellospora C. Walker et F.E. Sanders (Błaszkowski 2003). However, spores of Pacispora spp. form at the tip of more or less cylindrical hyphae (Fig. 14), and thus 
identically to those of Glomus spp., whereas spores of the genus Scutellospora origin from a bulbous sporogenous cell.

Of the known species of the genus Pacispora, only P. boliviana Sieverd. et Oehl forms spores of a similar colour to that of spores of $P$. robiginia (Oehl, Sieverding 2004). However, the upper surface of the structural laminate wall layer of spores of $P$. robiginia is smooth (Figs 9-14), and that of spores of $P$. boliviana is ornamented with shallow, usually pentagonal pits (Oehl, Sieverding 2004). Spores of the other species of this genus are colourless (Błaszkowski 2003; Oehl, Sieverding 2004).

Acknowledgment. This study was supported in part by The Committee of Scientific Researches, a grant no. 2 P04C 04128.

\section{REFERENCES}

An Z.-Q, Hendrix J. W., Hershman D. E., Ferriss R. S., Henson G. T. 1993. The influence of crop rotation and soil fumigation on a mycorrhizal fungal community associated with soybean. Mycorrhiza 3: $171-182$.

Bethlenfalvay G. J., Dakessian S., Pacovscky R. S. 1984. Mycorrhizae in a southern California desert: ecological implications. Can. J. Bot. 62: 519-524.

Błaszkowski J. 2003. Arbuscular mycorrhizal fungi (Glomeromycota), Endogone, and Complexipes species deposited in the Department of Plant Pathology, University of Agriculture in Szczecin, Poland. http://www.agro.ar.szczecin.pl/ jblaszkowski/.

Błaszkowski J., Blanke V., Renker C., Buscot F. 2004. Glomus aurantium and G. xanthium, new species in Glomeromycota. Mycotaxon 90: 447-467.

Błaszkowski J., Czerniawska B. 2006. The occurrence of arbuscular mycorrhizal fungi of the phylum Glomeromycota in Israeli soils. Acta Soc. Bot. Pol. 75: 339-350.

Cabello M., Gaspar L., Pollero R. 1994. Glomus antarcticum sp. nov., a vesicular-arbuscular mycorrhizal fungus from Argentina. Mycotaxon 60: 123-128.

Dalpé Y. 1989. Inventaire et repartition de la flore endomycorhizienne de dunes et de rivages maritimes du Quebec, du Nouveau-Brunswick et de la Nouvelle-Ecosse. Naturaliste can. (Rev. Ecol. Syst.) 116: 219-236.

Declerck S., Cranenbrouck S., Dalpé Y., Séguin S., Grandmougin-Ferjani A., Fontaine J., Sancholle M. 2000. Glomus proliferum sp. nov.: a description based on morphological, biochemical, molecular and monoxenic cultivation data. Mycologia 92: 1178-1187.

Gai J. P., Christie P., Feng G., Li X. L. 2006. Twenty years of research on biodiversity and distribution of arbuscular mycorrhizal fungi in China: a review. Mycorrhiza 16: 229-239.

Gerdemann J. W., Trappe J. M. 1974. The Endogonaceae in the Pacific Northwest. Myc. Memoir 5: $1-76$.

Gilmore A. E. 1968. Phycomycetous mycorrhizal organisms collected by open-pot culture methods. Hilgardia 39: 87-105.

Gopi K., Douds P, Douds D. 2000. Current advances in mycorrhizae research. APS Press. The American Phytopathological Society. St. Paul, Minnesota.

Hall I. R. 1977. Species and mycorrhizal infections of New Zealand Endogonaceae. Trans. Br. Mycol. Soc. 68: 341-356.

Jansa J., Mozafar A., Anken T., Ruh R., Sanders I. R., Frossard E. 2002. Diversity and structure of AMF communities as affected by tillage in a temperate soil. Mycorrhiza 12: 225-234.

Klironomos J. N., Hart M. M., Gurney J. E., Moutoglis P. 2001. Interspecific differences in the tolerance of arbuscular mycorrhizal fungi to freezing and drying. Can. J. Bot. 79: 1161-1166.

Kornerup A., Wanscher J. W. 1983. Methuen handbook of_colour. 3rd Ed. Eyre Methuen and Co. Ltd., London.

Koske R. E. 1985. Glomus_aggregatum emended: A distinct taxon in the Glomus fasciculatum complex. Mycologia 77: 619-630.

Koske R. E., Gemma J. N. 1996. Arbuscular mycorrhizal fungi in Hawaiian sand dunes: Island of Kaua'i. Pacific Sci. 50: 36-45. 
Koske R. E., Halvorson W. L. 1989. Mycorrhizal associations of selected plant species from San Miguel island, Channel Islands national Park, California. Pacific Sci. 43: 32-40.

Jansa J., Mozafar A., Anken T., Ruh R., Sanders I. R., Frossard E. 2002. Diversity and structure of AMF communities as affected by tillage in a temperate soil. Mycorrhiza 12: 225-234.

McGee P. A. 1986. Further sporocarpic species of Glomus (Endogonaceae) from South Australia. Trans. Brit. Mycol. Soc. 87: 123-129.

Mirek Z. H., Piękoś-Mirkowa H., Zając A., Zając M. 1995. Vascular plants of Poland. A Checklist. Polish Botanical Studies, Guidebook 15, Kraków, 303 pp.

Mohankumar V., Ragupathy S., Nirmala C. B., Mahadevan A. 1988. Distribution of vesicular arbusculr mycorrhizae (VAM) in the sandy beach soils of Madras coast. Cur. Sci. 57: 367-368.

Morton J. B. 2002. International Culture Collection of (Vesicular) Arbuscular Mycorrhizal Fungi. West Virginia University: http://www.invam.caf.wvu.edu/.

Oehl F., Sieverding E. 2004. Pacispora, a new vesicular arbuscular mycorrhizal fungal genus in the Glomeromycetes. J. Appl. Bot. 78: 72-82.

Oehl F., Sieverding E., Ineichen K., Ris E.-A., Boller T., Wiemken A. 2005. Community structure of arbuscular mycorrhizal fungi at different soil depths in extensively and intensively managed agroecosystems. New Phytol. 165: 273-283.

Oehl F., Wiemken A., Sieverding E. 2003. Glomus aureum, a new sporocarpic arbuscular mycorrhizal fungal species from European grasslands. J. App. Bot. 77: 111-115.

Omar M. B., L. Bollan L., Heather W. A. 1979. A permanent mounting medium for fungi. Bull. British Mycol. Soc. 13: 31-32.

Schenck N. C., Smith G. S. 1981. Distribution and occurrence of vesicular-arbuscular mycorrhizal fungi on Florida agricultural crops. Soil and Crop Sci. Soc. Florida 40: 171-175.

Schenck N. C., Smith G. 1982. Additional new and unreported species of mycorrhizal fungi (Endogonaceae) from Florida. Mycologia 74: 77-92.

Schwarzott D., Walker C., Schüßler A. 2001. Glomus, the largest genus of the arbuscular mycorrhizal fungi (Glomales) is nonmonophyletic. Mol. Phyl. Evol. 21: 190-197.

Sieverding E. 1987. A VA-mycorrhizal fungus, Glomus glomerulatum sp. nov., with two hyphal attachments and spores formed only in sporocarps. Mycotaxon 29: 73-79.

Stutz J. C., Morton J. B. 1996. Successive pot cultures reveal high species richness of arbuscular endomycorrhizal fungi in arid ecosystem. Can. J. Bot. 74: 1883-1889.

Stutz J. C., Copeman R., Martin C. A., Morton J. B. 2000. Patterns of species composition and distribution of arbuscular mycorrhizal fungi in arid regions of southeastern North America and Namibia, Africa. Can. J. Bot. 78: 237-245.

Stürmer S. L., Morton J. B. 1997. Developmental patterns defining morphological characters in spores of four species in Glomus. Mycologia 89: 72-81.

Turnau K., Ryszka P., Gianinazzi-Pearson V., van Tuinen D. 2001. Identification of arbuscular mycorrhizal fungi in soils and roots of plants colonizing zinc wastes in southern Poland. Mycorrhiza 10: 169-174.

Walker C. 1983. Taxonomic concepts in the Endogonaceae: Spore wall characteristics in species descriptions. Mycotaxon 18: 443-455.

Walker C. 1986. Taxonomic concepts in the Endogonaceae. II. A fifth morphological wall type in endogonaceous spores. Mycotaxon 25: 95-99.

Walker C., Koske R. E. 1987. Taxonomic concepts in the Endogonaceae: IV. Glomus fasciculatum redescribed. Mycotaxon 30: 253-262.

Walker C., Trappe J. M. 1993. Names and epithets in the Glomales and Endogonales. Mycol. Res. 97: 339-344.

Walker C., Vestberg M. 1994. A simple and inexpensive method for producing and maintaining closed pot cultures of arbuscular mycorrhizal fungi. Agr. Sci. Finland 3: 233-240.

Zhang M-Q., Wang Y-S. 1992. Eight species of VA mycorrhizal fungi from Northern China. Acta Mycol. Sinica 2: 258-267. 
Glomus intraradices i Pacispora robiginia, nowe dla Polski gatunki mikoryzowych grzybów arbuskularnych (Glomeromycota)

Streszczenie

Opisano i zilustrowano cechy morfologiczne zarodników i mikoryz Glomus intraradices oraz zarodników Pacispora robiginia, mikoryzowych grzybów arbuskularnych z gromady Glomeromycota. Ponadto przedstawiono poznane rozmieszczenie tych gatunków zarówno w Polsce, jak i w innych regionach świata. Oba te gatunki nie były wcześniej podawane z Polski i niniejszy artykuł jest drugim doniesieniem o występowaniu $P$. robiginia w świecie. 


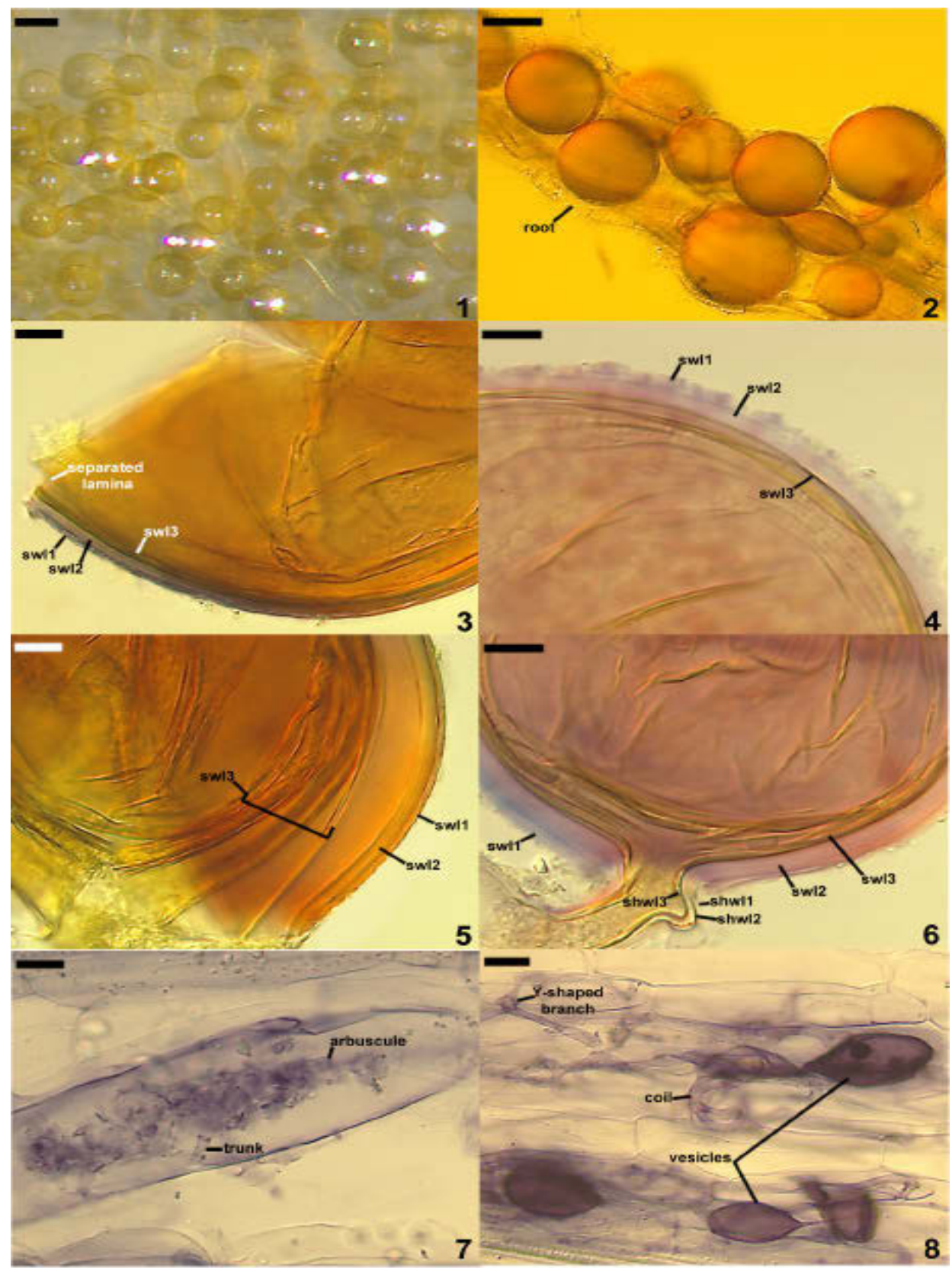

Figs 1-8. Glomus intraradices. 1. Loose aggregate of intact spores. 2. Intraradical spores. 3-5. Spore wall layers 1-3 (swl1-3). 6. Spore wall layers 1-3 (swl1-3) continuous with subtending hyphal wall layers 1-3 (shwl1-3). 7. Arbuscule with trunk. 8. Vesicles and straight, coiled, and Y-branched hyphae. Fig. 1, spores in lactic acid. Figs 2-6, spores crushed in PVLG+Melzer's reagent. Figs 7 and 8, mycorrhizae stained in $0.1 \%$ trypan blue. Fig. 1, bright field microscopy; Figs 2-8, differential interference contrast. Bars: Figs 3-7=10 $\mu \mathrm{m}$; Fig. $8=20 \mu \mathrm{m}$; Fig. $2=50 \mu \mathrm{m}$; Fig. $1=100 \mu \mathrm{m}$. 


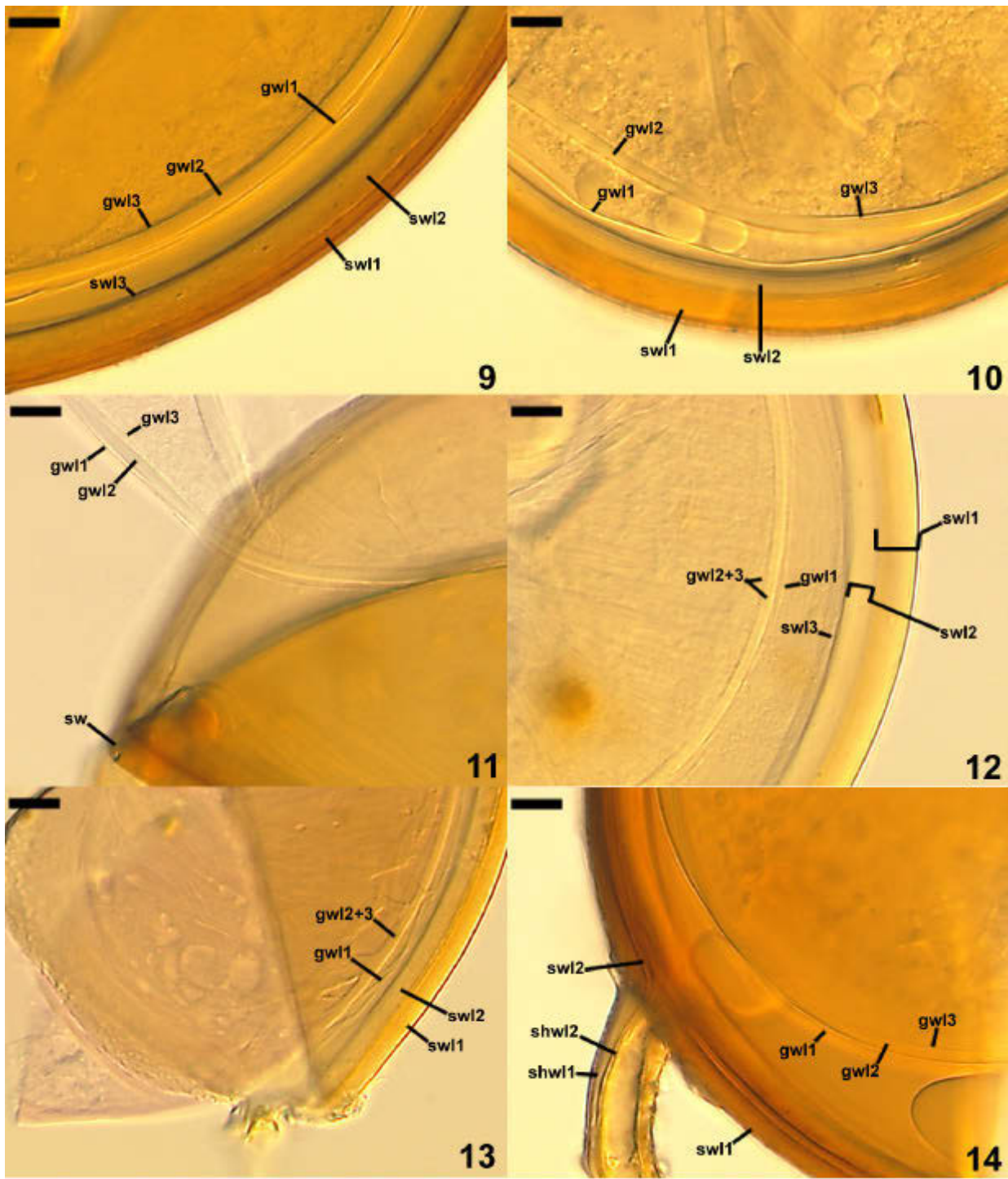

Figs 9-14. Pacispora robiginia. 9-13. Spore wall layers 1-3 (swl1-3) and inner germination wall layers 1-3 (gwl1-3). 14. Spore wall layers 1 and 2 (swl1 and 2) continuous with subtending hyphal wall layers 1 and 2 (shwl1 and 2). Figs 9-12 and 14, spores crushed in PVLG. Fig. 13, spore crushed in PVLG+Melzer's reagent. Figs 9-14, differential interference contrast. Bars: Figs 9-14=10 $\mu \mathrm{m}$. 